\title{
Simple Mobile Application for Calculating "Ergotrauma" Made Using an Excel Sheet
}

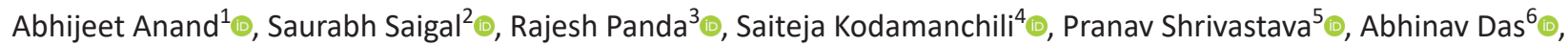
Krishnkant Bhardwaj ${ }^{7} \oplus$, Gowthaman TB $^{8} \odot$

Keywords: Ergotrauma, Formula, Mobile application.

Indian Journal of Critical Care Medicine (2021): 10.5005/jp-journals-10071-23948

Since the advent of positive pressure ventilation, the issue of ventilator-induced lung injury (VILI) has seen ever-ongoing evolution of theories from barotrauma (1973), followed by volutrauma (1988) and atelectotrauma (1967), to the most recent being ergotrauma (2016). ${ }^{1}$ Ergotrauma being the latest concept seems to incorporate all the factors involved in VILI, which includes respiratory rate $(R R)$, tidal volume $(\Delta V)$, positive-end expiratory pressure (PEEP), inspiratory-expiratory ratio (I:E ratio), airway resistance $\left(R_{\mathrm{aw}}\right)$, and respiratory system elastance $\left(E_{\mathrm{RS}}\right) .^{2}$ There are many formulas to calculate the mechanical power being delivered to the respiratory system with every breath, and most of them are mathematically complex to be calculated bedside. ${ }^{3}$ We used the following formula with modification for elastance $\left(E_{\mathrm{RS}}\right)$ as the inverse of compliance $\left(C_{\mathrm{RS}}\right)$ for making an application using a simple excel sheet formula. ${ }^{3}$

$$
\begin{aligned}
\text { Power }_{\mathrm{RS}}= & 0.098 \times R R \times\left\{\Delta V^{2} \times\left[\left(0.5 \times E_{\mathrm{RS}}+R R\right.\right.\right. \\
& \left.\left.\left.\times(1+\mathrm{I}: \mathrm{E}) / 60 \times \mathrm{I}: \mathrm{E} \times R_{\mathrm{aw}}\right)+\Delta V \times \mathrm{PEEP}\right]\right\}
\end{aligned}
$$

The excel sheet is used for the calculation of various data by formulating equations, but the excel sheet is itself quite cumbersome to use in mobile phone's small screens. So, we used an application called "Open As App" available on the Android Play Store as well as on their website www.openasapp.com. In this app by simply uploading the excel sheet, with various variables as parts of the formula, we were able to make a simple application that can be used bedside by entering the ventilator parameters like PEEP ( $\left.\mathrm{cm} \mathrm{H}_{2} \mathrm{O}\right)$, tidal volume $(\mathrm{mL})$, inspiratory-expiratory ratio (I:E ratio), $\mathrm{RR}(\mathrm{bpm})$, compliance $\left(\mathrm{mL} / \mathrm{cm} \mathrm{H}_{2} \mathrm{O}\right)$, and airway resistance ( $\mathrm{cm} \mathrm{H}_{2} \mathrm{O} / \mathrm{L} / \mathrm{sec}$ ). The power thus calculated was given in $\mathrm{J} / \mathrm{min}$. The app can be used by visiting https://oaa.app.link/NF1iuf4yP9 and then downloading "Open As App" as prompted.

We want to stress that applications like "Open As App" can help us make simple applications for various complex formulas used in critical care medicine, just by using an excel sheet. It will help in accurate calculation and ease of use of such formulas at the bedside and open new avenues in patient management.
${ }^{1-8}$ Department of Anaesthesiology and Critical Care, All India Institute of Medical Sciences, Bhopal, Madhya Pradesh, India

Corresponding Author: Abhijeet Anand, Department of Anaesthesiology and Critical Care, All India Institute of Medical Sciences, Bhopal, Madhya Pradesh, India, e-mail: abhijeet.anand@hotmail.com

How to cite this article: Anand A, Saigal S, Panda R, Kodamanchili S, Shrivastava P, Das A, et al. Simple Mobile Application for Calculating "Ergotrauma" Made Using an Excel Sheet. Indian J Crit Care Med 2021;25(9):1081.

Source of support: Nil

Conflict of interest: None

\section{OrCID}

Abhijeet Anand (10 https://orcid.org/0000-0001-6498-5388 Saurabh Saigal @ https://orcid.org/0000-0002-2364-2271 Rajesh Panda (1) https://orcid.org/0000-0001-7123-876X Saiteja Kodamanchili (ㅇ https://orcid.org/0000-0003-1033-0321 Pranav Shrivastava (1) https://orcid.org/0000-0003-1637-1271 Abhinav Das @ 1 https://orcid.org/0000-0003-4500-5537 Krishnkant Bhardwaj @ https://orcid.org/0000-0002-2207-0654 Gowthaman TB 으 https://orcid.org/0000-0002-0301-3793

\section{References}

1. Tonetti T, Vasques F, Rapetti F, Maiolo G, Collino F, Romitti F, et al. Driving pressure and mechanical power: new targets for VILI prevention. Ann Transl Med 2017;5(14):286. DOI: 10.21037/ atm.2017.07.08.

2. Gattinoni $L$, Tonetti $T$, Cressoni $M$, Cadringher $P$, Herrmann $P$, Moerer $O$, et al. Ventilator-related causes of lung injury: the mechanical power. Intensive Care Med 2016;42:1567-1575. DOI: 10.1007/s00134-016-4505-2.

3. Rahaman U. Mathematics of ventilator-induced lung injury. Indian J Crit Care Med 2017;21(8):521-524. DOI: 10.4103/ijccm. IJCCM_411_16.

(0) Jaypee Brothers Medical Publishers. 2021 Open Access This article is distributed under the terms of the Creative Commons Attribution 4.0 International License (https://creativecommons.org/licenses/by-nc/4.0/), which permits unrestricted use, distribution, and non-commercial reproduction in any medium, provided you give appropriate credit to the original author(s) and the source, provide a link to the Creative Commons license, and indicate if changes were made. The Creative Commons Public Domain Dedication waiver (http://creativecommons.org/publicdomain/zero/1.0/) applies to the data made available in this article, unless otherwise stated. 